\title{
Enhancing Online Interactivity \& Engagement: Impacting Student Learning
}

\author{
Nola Stair \\ University of Greenwich, Business School
}

\section{Introduction}

Over the past 10 years, the University of Greenwich Business School has been integrating the use of technology into the teaching and learning process with various tools (e.g., digital images, podcasts, simulations, software applications, video cameras and whiteboards). Electronic communication between administrators, academics and students has been enhanced beyond e-mail to regularly include blogs, online discussion boards, videoconferencing and wikis. Today, many of these technology tools are components housed within a virtual learning environment (VLE). Therefore, the recent 2011 campuswide selection of a new VLE (i.e, Moodle) had significant implications for the Business School's continued development of e-learning practice and pedagogy.

At a minimum, all Business School courses provide online access to instructional materials, Q \& A discussion boards, and coursework submission. However, some courses have moved to the next level by expanding the use of the VLE's capabilities to enhance interactivity and engagement with students. This integration of traditional face-to-face (F2F) instruction and VLE tools is commonly known as blended learning. It has been suggested by educational research that the design and development of effective and engaging interactive learning experiences has a direct impact on student learning. (Moore, 1993). In a fully online (or blended) environment, interaction can take place synchronously or asynchronously depending on the technology tool used (e.g., chat rooms, discussion boards, wikis, blogs).

This case study examines asynchronous interaction and engagement with Business School undergraduate and graduate students over a three year period; few other studies have investigated online engagement over an extended length of time. It illustrates an overall course redesign process in response to learning experiences that attempts to:

- increase student interaction with course materials independently of tutorials and lectures,

- encourage more reflective practice on essay writing capabilities (from both the tutor and student perspective), and

allow more productive use of face-to-face instructional time. 


\section{Online Interaction}

Key aspects of online interaction have emerged from computer-mediated communication (CMC) research, which involves exchanging information over a network. As technology has changed, different types of CMC delivery platforms have also developed; however, the main underlying concepts of interactivity and active learning are useful methods to manage and structure course design. This case study focuses on the use of VLE discussion boards, which, as noted by West and Graham (2007) are often under-utilized as many academics struggle to adapt them effectively as an effective method that can maximize student learning. Another common area of misunderstanding centres around the belief that the management of discussion board activities is too time-consuming.

As part of the new VLE selection process, an analysis of VLE tool usage among the Schools within the University of Greenwich was conducted by the Web Services office in 2010 and the following extract focuses on discussion board activity:

Table 1 Discussion Board Usage in Schools

\begin{tabular}{|l|c|c|c|c|}
\hline & $\begin{array}{c}\text { Architecture \& } \\
\text { Construction }\end{array}$ & Business & $\begin{array}{c}\text { Education \& } \\
\text { Training }\end{array}$ & English \\
\hline \# of active VLE courses & 124 & 603 & 59 & 304 \\
\hline \# of courses using discussion boards & 5 & 439 & 27 & 21 \\
\hline \% of courses using discussion boards & $4 \%$ & $73 \%$ & $16 \%$ & $7 \%$ \\
\hline
\end{tabular}

While Q \& A discussion boards are available in all Business School courses; posting of messages by students is minimal. To minimize the struggle and misunderstanding surrounding discussion boards, as well as maximize usage without being too time consuming, it is helpful to understand the ways in which online discussions can be integrated into a traditional face-to-face course. Jung (1995 cited by Paulson 2002) identified four types of communication: one-alone, one-to-one, one-to-many, and many-to-many interaction, while Moore (1993) focused on the specific instructional distinctions:

\footnotetext{
- learner-content,

- learner-teacher and

-. learner-learner interaction
}

The learner-content approach involves the student interacting with instructional materials to gain knowledge with little or no feedback from others. With learner-teacher engagement, this provides opportunities for discussion and feedback about students' learning experiences, which closely mirrors the traditional classroom experience. Learner-learner extends the learner-teacher approach to include peers in a socially-mediated collaborative approach.

It is important for educational developers to consider this continuum of online interaction in order to develop appropriate pedagogical strategies that take advantage of a technology tool's functionality and fit for purpose. Otherwise, as Casey and Wilson (2005) noted the concept of 'social constructivism' during the teaching and learning process, (i.e., creating meaning through interactions with others) is "often an 
ambition, rather than reality" ( $p$ 8). Too often, online interaction focuses on learner-content, rather than learnerteacher or learner-learner in which the latter two focus on designing, facilitating and managing the constructivist activities of the students.

After identifying the pedagogical considerations in terms of the course curriculum, interaction continuum and technology tools, this case study will provide insight into how discussion boards can enhance learnerteacher and learner-learner interaction to provide ongoing feedback, without becoming overwhelmed in the process.

\section{Course Design Approach}

Three courses from BA Hons Business Studies and MBA programmes - in the Systems Management and Strategy department - were re-conceptualized to incorporate online learner-teacher and learner-learner interaction, as presented in Table 2 below:

\begin{tabular}{|c|c|c|c|}
\hline Case & Level and Course & $\begin{array}{c}\text { Goal of } \\
\text { Online Interaction }\end{array}$ & $\begin{array}{l}\text { Required Online } \\
\text { Interaction } \\
\text { (\% of Assessment) }\end{array}$ \\
\hline 1 & $\begin{array}{c}\text { Undergraduate 1st Year } \\
\text { Personal and Professional } \\
\text { Development }\end{array}$ & $\begin{array}{l}\text { increase student } \\
\text { interaction with course } \\
\text { materials independently } \\
\text { of tutorials and lectures }\end{array}$ & $10 \%$ \\
\hline 2 & $\begin{array}{c}\text { Undergraduate Final Year } \\
\text { Thematic Independent } \\
\text { Studies }\end{array}$ & $\begin{array}{l}\text { encourage formative self } \\
\text { reflective practice of } \\
\text { research and writing skills }\end{array}$ & 0 \\
\hline 3 & $\begin{array}{c}\text { Graduate (MBA) } \\
\text { Foundations of } \\
\text { Scholarship \& Research } \\
\text { Methods }\end{array}$ & $\begin{array}{l}\text { encourage formative self } \\
\text { reflective practice of } \\
\text { research and writing skills }\end{array}$ & $5 \%$ \\
\hline
\end{tabular}

A brief overview, assessment structure, and analysis of online interactivity in terms of learner-content, learnerteacher and learner-learner interaction is presented for each case. 


\section{Case 1}

Personal \& Professional Development I (PPD1) is taught in a F2F environment with approximately 120 students split into 8 tutorials. As United Kingdom (UK) higher education guidelines, this course assists students with their own personal, educational, and career development. They complete various assignments and tasks - both individually and in groups - before submitting their final coursework.

There are four elements of assessment - a reflective report, two portfolios and participation. However, participation was re-conceptualized into two elements - F2F attendance/contribution in tutorials and "virtual" contribution to online discussions. For online discussions, students were asked to participate in structured personal development activities in which they interact with each other, the course content and/ or one-on-one with their personal tutor (see Table 3). Their virtual participation was automatically tracked by the virtual learning environment and equaled $50 \%$ of their $\mathrm{F} 2 \mathrm{~F}$ attendance requirement.

Table 3 Analysis of Online Discussion Board Activities/Tasks and Online interaction

\begin{tabular}{|l|c|c|c|}
\hline Online Discussion Activities/Tasks & $\begin{array}{c}\text { Learner- } \\
\text { Content }\end{array}$ & $\begin{array}{c}\text { Learner- } \\
\text { Teacher }\end{array}$ & $\begin{array}{c}\text { Learner- } \\
\text { Learner }\end{array}$ \\
\hline 1 - Introductions & -- & $x$ & $x$ \\
\hline $2-$ Technology Checklist & $x$ & $x$ & $x$ \\
\hline $3-$ YouTube Videos about Presentations & $x$ & -- & $x$ \\
\hline $4-$ CV and Cover Letter & $x$ & $x$ & -- \\
\hline $5-$ Personal Development Plan & $x$ & $x$ & $x$ \\
\hline
\end{tabular}

Figure 1 shows the structure of one tutorial's discussion boards with 12 students. As part of establishing a constructivist community for 1st year undergraduate students, the online activities supported the development of their final coursework and were not formally graded. By carefully integrating the online activities to correlate with their submitted graded coursework:

- face-to-face discussions were extended beyond the limited tutorial time through the online discussion with personal tutors,

private feedback was provided by tutors regarding their students' CVs and personal development plans, and

additional online resources were available for reflection and discussion to enhance their own upcoming group presentations. 


\section{Tutorial 6B - Nola Stair $\cong($ Conditional) (42 Messages)}

This private discussion area is for posting your technology checklist, PPD Plan, and CV/Cover Letter.

Tutorial 6B Only - Private Discussion with Nola Stair $\cong$ ( 43 Messages)

Please let Nola Stair know any concerns you may have, such as:

-Which general aspects of university are going well or not going well?

-Which subjects are going well or not going well?

Giving Presentations $\cong$ (12 Messages / 4 New )

Which were the best and worst presentations in the Web Links section? Why?

\section{Introduce Yourself! $\cong$ (54 Messages / 2 New )}

Describe one accomplishment that you want to achieve, such as a personal/professional aspiration or lifetime goals. Be very specific in explaining why you want to achieve these accomplishments and how they will impact on your life. Then, read and respond to at least one other student's posting.

Figure 1 Case 1: Design of Online Discussion Board Activities/Tasks

\section{Case 2}

Thematic Independent Studies (TIS) is one of two capstone courses which final year students can select and is taught in a F2F environment with approximately 180-200 students split into 11 bi-weekly tutorials. In TIS, students write two extended essays (i.e., literature review and critical analysis), which draw on relevant academic literature and secondary data.

According to Healy and Jenkins (2009), there are four main ways of engaging undergraduate students with research and inquiry:

- research-led: learning about current research

- research-oriented: developing research skills and techniques

research-based: undertaking research and inquiry

- research-tutored: engaging in research discussions

However, while many dissertation courses focus on research-led and research-oriented methods of delivery, TIS also provided both F2F and online opportunities to engage students in research-based and research-tutored activities. Instead of public online discussion boards, private ones were configured as "personal journals" which were only viewable between each student and his/her personal tutor. Through their personal journals (see Table 4), students uploaded work-in-progress for ongoing formative feedback:

Table 4 Analysis of Online Personal Journals and Online Interaction Continuum

\begin{tabular}{|c|c|c|c|}
\hline Online Personal Journal & $\begin{array}{l}\text { Learner- } \\
\text { Content }\end{array}$ & $\begin{array}{l}\text { Learner- } \\
\text { Teacher }\end{array}$ & $\begin{array}{l}\text { Learner- } \\
\text { Learner }\end{array}$ \\
\hline \multicolumn{4}{|l|}{ Feedback: } \\
\hline - Mind Map & $x$ & $x$ & -- \\
\hline - Essay Outlines & $x$ & $x$ & -- \\
\hline - Essay Drafts & $x$ & $x$ & -- \\
\hline
\end{tabular}


Figure 2 below shows the structure of one tutorial's discussion boards with approximately 15-20 students. In one centralized area, the tutor was able to establish key checkpoints in the following ways:

$\cdots$ gauge student progression (e.g., development of mind maps, formulation of research questions, use of logs recording online database searches) and

- provide ongoing feedback during the development of student essays (e.g., outlining themes found in literature, suggesting additional resources for further investigation, reviewing writing and summarizing skills).

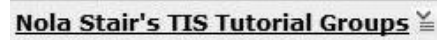

Dof Essay \#1 $\cong$ (164 Messages)

This is a private area so that you can post your mind map, outlines and essay sections (1-2 pages) so that your TIS tutor can work with you to fine-tune your theme and essay questions. It is not the your tutor's role to read your entire essay before the submission deadline.

Please allow at least 24-48 hours for a response.

Fos Essay \#2 $\cong$ (96 Messages / 14 New )

This is a private area so that you can post your mind map, outlines and essay sections (1-2 pages) so that your TIS tutor can work with you to fine-tune your theme and essay questions. It is not the your tutor's role to read your entire essay before the submission deadline.

Figure 2 Case 2: Design of Online Discussion Board Activities/Tasks

\section{Case 3}

Foundations of Scholarship \& Research Methods (FSRM) is an introductory 10 week course that is designed to develop students' knowledge and understanding of academic practice and research. It is taught in a F2F environment with approximately 45-50 students. The problem-based teaching approach centres on the submission of formative portfolio tasks and a research proposal. Many of the tasks require interaction between students.

While the benefits of peer review have been widely published (Knight and Steinbach 2011), the use of technology can help facilitate the process as there are specialized software programs available for purchase or use over the Internet. However, a simple and easy solution was found by using the VLE's discussion board (see Table 5) that incorporated all levels of the interaction continuum as students progressed through Tasks 1, 5 and 6 :

- Task 1 - students drafted short essays defining 'critical thinking' for posting

. Task 5 - each student selected one draft and provided online peer feedback.

- Task 6 - each student reflected upon how it will be used to improve their draft 
Table 5 Analysis of Discussion Board and Online Interaction Continuum

\begin{tabular}{|c|c|c|c|}
\hline Online Discussion Board & $\begin{array}{l}\text { Learner- } \\
\text { Content }\end{array}$ & $\begin{array}{l}\text { Learner- } \\
\text { Teacher }\end{array}$ & $\begin{array}{l}\text { Learner- } \\
\text { Learner }\end{array}$ \\
\hline \multicolumn{4}{|l|}{ Portfolio: } \\
\hline - Task 1 - Essay Draft & $x$ & $x$ & $x$ \\
\hline - Task 2 - Online Referencing Quiz & $x$ & -- & -- \\
\hline - Task 3 - Plagiarism Reflection & -- & -- & $x$ \\
\hline - Task 4 - Journal Article Review & $x$ & -- & -- \\
\hline - Task 5 - Peer Feedback & $\mathrm{x}$ & $x$ & $x$ \\
\hline - Task 6 - Reflection on Peer & -- & $x$ & -- \\
\hline - Task 7 - Time Management Simulation & $\mathrm{x}$ & -- & $\mathrm{x}$ \\
\hline
\end{tabular}

Figure 3 below shows the structure of one tutorial's discussion boards with approximate 45-50 students. Instead of passing around hard copies of student drafts during F2F seminars in order to complete Tasks 1, 5 and 6, the online discussion board provided an efficient delivery mechanism in which students could interact with each other. With one centralized area, the tutor was also able to review all drafts and then post messages summarizing or highlighting good areas of practice in which all students can benefit.

\section{Foundations of Scholarship $\cong$}

Please note that there are no discussion boards or feedback opportunities for Task 3 and 7.

$\square$ Introductions $\cong$ (221 Messages / 218 New )

Please post your 200 word Introductions. You are encouraged to reply to at least two introductions.

Q Tasks 1 and 5 - Receiving Feedback2 $\cong$ (417 Messages / 4 New )

Part A - Post your Task 1 - "Critical Thinking" report on the discussion board. As other students' reports are posted, select ONLY ONE and provide your feedback to someone else. Demonstrate your critical thinking skills:

o What do you think is the strongest argument for the author's position? Why?

o What do you think is the weakest argument for the author's position? Why?

o What do you find most compelling about this paper? What needs to be impr...more

Figure 3 Case 3: Design of Online Discussion Board Activities/Tasks 


\section{Results and Discussion}

The integration of technology tools (i.e., discussion boards, private journals) has introduced new methods of teaching and opportunities for learning. It has also highlighted online communication and interaction challenges which need further investigation. Quantitative data was downloaded from the VLE to analyse discussion board usage in Case 1, qualitative data was summarized from student feedback in Case 2 and both quantitative data/qualitative in Case 3 highlights the use of peer feedback.

\section{Case 1}

Prior to the integration of online discussion boards, many PPD1 tutors commented that students arrived unprepared for tutorials having not engaged with course materials independently or were passively involved during tutorials. Table 6 below provides triangulation of student F2F vs virtual participation data from 2010-2011. Over the past 3 years, there had been a steady increase in both F2F attendance and online engagement with PPD1 tutors; however, it is evident that some students still make little or no use of the discussion boards to engage with their PPD1 tutors.

Table 6. VLE (WebCT) User Statistics 2010-2011

\begin{tabular}{|c|c|c|c|c|}
\hline Tutorial & \# of Students & $\begin{array}{c}\text { Average F2F } \\
\text { Attendance \% }\end{array}$ & $\begin{array}{c}\text { Average Virtual } \\
\text { Attendance } \%\end{array}$ & $\begin{array}{c}\text { Combined } \\
\text { F2F+Virtual } \\
\text { Attendance } \%\end{array}$ \\
\hline A & 14 & 76 & 61 & 69 \\
\hline B & 17 & 74 & 66 & 70 \\
\hline C & 13 & 58 & $\mathbf{3 7}$ & 58 \\
\hline D & 19 & 70 & 50 & 66 \\
\hline E & 14 & 79 & 49 & 64 \\
\hline F & 13 & 62 & $\mathbf{1 4}$ & $\mathbf{3 8}$ \\
\hline G & 13 & 60 & 46 & 53 \\
\hline H & 120 & $\mathbf{7 0}$ & 48 & 59 \\
\hline Total & & & & 53 \\
\hline
\end{tabular}


Table 7 below provides 2011-2012 data from the new VLE (Moodle). Although there was an increase in tutorials (along with fewer students), one tutorial had significantly less F2F and virtual attendance. Again, several tutorials contained students who made little or no use of the discussion boards.

Table 7 VLE (Moodle) User Statistics 2011-2012

\begin{tabular}{|c|c|c|c|c|}
\hline Tutorial & \# of Students & $\begin{array}{c}\text { Average F2F } \\
\text { Attendance } \%\end{array}$ & $\begin{array}{l}\text { Average Virtual } \\
\text { Attendance } \%\end{array}$ & $\begin{array}{c}\text { Combined } \\
\text { F2F+Virtual } \\
\text { Attendance } \%\end{array}$ \\
\hline A & 12 & 78 & 43 & 62 \\
\hline B & 12 & 78 & 45 & 61 \\
\hline C & 14 & 68 & 68 & 68 \\
\hline D & 10 & 68 & 33 & 49 \\
\hline $\mathrm{E}$ & 9 & 74 & 28 & 51 \\
\hline $\mathrm{F}$ & 8 & 52 & 47 & 49 \\
\hline G & 12 & 37 & 42 & 39 \\
\hline $\mathrm{H}$ & 12 & 54 & 35 & 45 \\
\hline 1 & 10 & 80 & 55 & 67 \\
\hline $\mathrm{J}$ & 15 & 64 & 41 & 53 \\
\hline Total & 114 & 58 & 43 & 49 \\
\hline
\end{tabular}

This reversal in both F2F and virtual attendance could result from several factors:

- positioning of discussion board areas in Moodle's weekly content design; instead of one centralized area containing all discussion boards (as with WebCT)

- limited demonstration of Moodle's features by PPD1 tutors during tutorial time

- limited discussion of online activities during 1on1 sessions with students

$\ldots$ limited Personal Tutor training of new PPD1 tutors.

However, the data will be used for reflection during team meetings and to pinpoint areas of staff development needed to ensure that PPD1 tutors are aware of their role in engaging students - both F2F and online - as the discussion board activities were designed not to be time-consuming, but as a helpful resource to support their students with fulfilling coursework. 


\section{Case 2}

Since TIS meets bi-weekly, students are expected to progressively develop their essays; however, many wait until the week before submission to begin writing their essays. However, by providing ongoing feedback during the development of their essays, Nicol and Macfarlane-Dick (2006) argue that this type of empowerment of students will give them practice in managing and evaluating aspects of their own learning.

As shown previously in Table 2, students were not required to participate in the private online discussion boards (i.e, private journals) and at first, very few students took advantage of this tool. However, it was noticed that students, who were initially reluctant to engage with their tutors online about their essays, gained more confidence with using the private discussion board as a means of obtaining feedback for their work-in-progress after listening to the positive experiences and feedback tips provided to other students during the F2F tutorial.

Since tutorials met bi-weekly, the online private discussions extended opportunities to review and offer suggestions about mind maps, outlines and journal article database searches. This allowed more productive use of F2F instructional time to be spent on specific problems, which are also shared and reflected upon with their peers. Several students commented in their reflective reports about how helpful the online communication enabled them to progress with their coursework throughout both terms:

- "The tutorial was another important place of learning as students were well delighted in sharing views regarding any essay topic of their interest and feedback was given immediately."

.o "I found the discussion board to be another useful process as it has proven beneficial to me when I am in need of help during struggling times. I used it to contact my tutor, seeking help and she responded promptly with clear advice and direction which helped me a great detail."

Students, who did not post any messages throughout the terms, reflected that they realized they should have taken advantage of the discussion boards to ask questions, share draft ideas or concerns as they felt it would have resulted in better marks on their essays:

.0 "I should have been more willing to discuss my topic with my tutor on the discussion board as it could have prevented my first essay from suffering."

. "I could have done with a bit more advice and help from my tutor."

Overall, for several TIS tutorials, the availability of the online personal journal engaged students in brainstorming, outlining and drafting their essays much earlier in the process - knowing that ongoing feedback would be provided to guide their work. Also, student feedback specifically indicated a preference for private communication during the early stages of their budding research ideas. Then, after online reflection and discussion with their tutor in which students examined their work and determined which areas of their draft work needed improvement, they felt more confident and comfortable with sharing select aspects of their draft work with peers in the F2F tutorials.

(Note: Unfortunately, at the time of publication, the basic installation of the University of Greenwich's new VLE (Moodle) does not provide automatically-configured private discussion boards, blogs, journals, or wikis. However, requests have been made to the Moodle implementation team so that the free open source plug-in developed by the Open University can be incorporated into Moodle's current functionality). 


\section{Case 3}

For the FSRM portfolio tasks, the use of the online discussion boards for the peer review process provided an efficient organizational method of providing multiple instances of the "same task" to allow for reflection and evaluation among students. The peer review process also empowered students to practice managing and evaluating not only their work - but the work of others. As Nicol and Macfarlane-Dick (2006) also suggest, this type of redesign creates more student interaction with the assessment criteria before the task is actually submitted. This was seen as students read as many drafts as they liked, instead of just the one draft they selected to provide feedback.

In Figure 4, a snapshot of engagement patterns showed that students read numerous drafts and comments posted by other classmates beyond the minimum requirement (see column "Total Messages Read") but did not necessarily respond. This is known as "lurking" - a virtual interaction that would be hard to replicate in a traditional F2F environment.

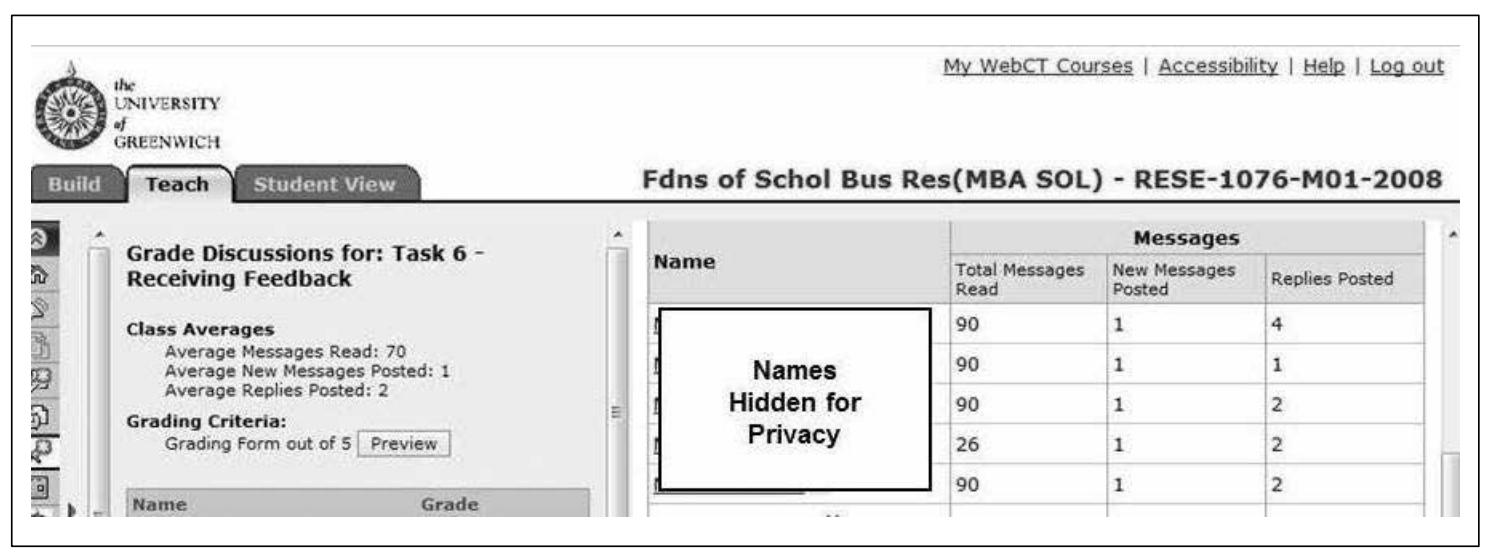

Figure 4 VLE (WebCT) User Statistics 2008-2009 (Messages-Read, Posted, Replied)

Overall, feedback from MBA graduate students indicated that they had more flexibility and convenience completing the task online, felt comfortable with the online peer dialogues, expressed gratitude for the amount of feedback, and most importantly, would like to have peer feedback opportunities for coursework throughout their MBA programme. These results will be shared with the MBA programme leader and teaching team, as Knight and Steinbach (2011) note that few courses in which writing is not the primary activity being reviewed, peer review is seldom used. This case demonstrated that technology can help increase student engagement with coursework - with little instructor involvement in managing the entire process. 


\section{Conclusion}

This case study has explored the learner-content, learner-teacher and learner-learner interaction continuum within three courses to analyse and reflect upon the level of interaction occurring (depending on the course's goals/objectives), as well as to explore the types of learning activities and feedback opportunities that can be linked with online discussions. The interaction continuum was used as a starting point to analyse potential formative online activities and tasks to support students as they progress with their coursework.

As course leader for all three courses, as well as one of the Business School's learning technologists, it was important to be cognizant of incorporating too much online interaction for PPD1 tutors who were not comfortable or familiar with using the tools. Therefore, the tutors had the flexibility of responding to students online or simply using the discussion board as a submission area for formative tasks to be reviewed during 1on1 meetings with students. The entire team of TIS tutors had the option of incorporating discussion boards but felt more comfortable offering feedback in person but began to realize the potential of the discussion board for future use. As the only tutor for FSRM, other MBA tutors have begun asking about the use of peer feedback in their courses as a developmental tool.

Past research in CMC has shown that online discussions will not automatically engage students and improve interaction without careful course and discussion design. However it is important to note that while active participation in online discussions may be influential for some students' learning, it may be difficult for other students due to a variety of reasons - cultural, educational, language and social background (Gulati, 2004). As seen in Case 1, this is an area of further investigation of and reflection among the PPD1 course leader and tutors.

Some suggestions for integrating the use of discussion boards, blogs, or wikis, while avoiding a significant amount of time managing online activity:

- Keep it simple - think about one specific course objective and how students might benefit from formative online feedback.

- Set realistic expectations about when/what you will be able to read and how many postings you will respond to each week. Be sure to inform students.

- Set specific deadlines for posting drafts if students would like formative feedback. Remind students that no feedback will be given within a certain time period before the final submission.

- Refer to virtual discussions in class, as students appreciate that someone has read and responded to their ideas. Use these postings as "teachable moments" if student permission has been granted ahead of time.

- Regularly browse the discussion boards 2-3 times each week depending on the task students are completing. This will spread out time spent online into manageable segments. Inform students if you did (or didn't) see any postings.

It is quite possible that you will notice:

- decreased amount of time spent on marking final submissions since formative feedback has guided students with clear targets for improvement and specific next steps.

- better tracking of previous feedback to students when using private online journals as a centralized area for communicating with students. 
higher levels of engagement from students during F2F tutorials as background work or developmental activities have been completed.

As a result of this three year preliminary evaluation, it has provided a broader basis to understand how students can take more interest and ownership in their learning by increasing online engagement opportunities with their coursework. The preliminary findings reinforce the concept that common VLE tools (e.g., discussion boards, private journals), combined with re-conceptualized flexible learning experiences, provide additional opportunities for students to contact tutors personally, discuss real-life content-related tasks asynchronously with their peers and/or tutors, and learn from their reflective experiences in online private journals or public discussion boards. Table 8 highlights of the re-design journey and shows the progression of interactivity design:

Table 8. Evolution of Course Redesign

\begin{tabular}{|c|c|c|c|}
\hline & $\begin{array}{c}\text { Case 1 - } \\
\text { Undergraduate } \\
\text { 1st Year Personal and Professional } \\
\text { Development }\end{array}$ & $\begin{array}{c}\text { Case } 2 \text { - } \\
\text { Undergraduate } \\
\text { Final Year } \\
\text { Thematic Independent Studies }\end{array}$ & $\begin{array}{c}\text { Case 1 - } \\
\text { MBA Foundations of } \\
\text { Scholarship and Research } \\
\text { Methods }\end{array}$ \\
\hline 2007 & $\begin{array}{l}\text { F2F } \\
\text { - document repository } \\
\text { - coursework submission } \\
\text { - generic Q\&A forums }\end{array}$ & $\begin{array}{l}\text { F2F } \\
\text { - document repository } \\
\text { - coursework submission } \\
\text { - generic Q\&A forums }\end{array}$ & $\begin{array}{l}\text { F2F } \\
\text { - document repository } \\
\text { - coursework submission } \\
\text { - generic Q\&A forums }\end{array}$ \\
\hline 2008 & $\begin{array}{l}\text { F2F } \\
\text { - document repository } \\
\text { - coursework submission } \\
\text { - variety of online activities } \\
\text { and resources }\end{array}$ & $\begin{array}{l}\text { Blended } \\
\text { - document repository } \\
\text { - coursework submission } \\
\text { - use of public/private } \\
\text { discussion boards } \\
\text { - additional links and } \\
\text { resources }\end{array}$ & $\begin{array}{l}\text { F2F and Online } \\
\text { - document repository } \\
\text { - coursework submission } \\
\text { - similar interactive activities } \\
\text { - additional links and } \\
\text { resources }\end{array}$ \\
\hline 2009 & $\begin{array}{l}\text { Blended } \\
\text { - document repository } \\
\text { - coursework submission } \\
\text { - variety of online activities } \\
\text { and resources } \\
\text { - discussion board activities = } \\
\text { part of attendance mark }\end{array}$ & $\begin{array}{l}\text { Blended and Online } \\
\text { - document repository } \\
\text { - coursework submission } \\
\text { - use of public/private } \\
\text { discussion boards with } \\
\text { interactive tasks } \\
\text { - audio podcasts } \\
\text { - links and resources }\end{array}$ & $\begin{array}{l}\text { Blended and Online } \\
\text { - document repository } \\
\text { - coursework submission } \\
\text { - incorporation of best online } \\
\text { interactivity into F2F course } \\
\text { - links and resources }\end{array}$ \\
\hline 2010 & $\begin{array}{l}\text { Blended } \\
\text { - document repository } \\
\text { - coursework submission } \\
\text { - variety of online activities } \\
\text { and resources } \\
\text { - discussion board activities = } \\
\text { part of attendance mark } \\
\text { - student vodcasts (video) }\end{array}$ & $\begin{array}{l}\text { Blended } \\
\text { - document repository } \\
\text { - coursework submission, use } \\
\text { of public/private discussion } \\
\text { boards with interactive tasks } \\
\text { - incorporated lecture capture } \\
\text { system } \\
\text { - student vodcasts (video) }\end{array}$ & $\begin{array}{l}\text { Blended and Online } \\
\text { - document repository } \\
\text { - coursework submission } \\
\text { - incorporation of best online } \\
\text { interactivity into F2F course } \\
\text { - links and resources } \\
\text { incorporated lecture capture } \\
\text { system } \\
\text { - student vodcasts (video) }\end{array}$ \\
\hline
\end{tabular}




\section{References}

Casey, J. \& Wilson, P. (2005). A Practical Guide to Providing Flexible Learning in Further and Higher Education. Quality Assurance Agency for Higher Education Scotland, Glasgow. [Online]. Available at: http// www.enhancementthemes.ac.uk/documents/flexibleDelivery/FD_Flexible_Learning_JCaseyFINALWEB.pdf. [Accessed 15 November 2010].

Gulati, S. (2004, April). Constructivism and Emerging Online Learning Pedagogy: A Discussion for Formal to Acknowledge and Promote the Informal. Paper presented at the Annual Conference of the Universities Association for Continuing Education - Regional Futures: Formal and Informal Learning Perspectives, Centre for Lifelong Learning, University of Glamorgan, 5-7 April, 2004.

JISC (2004). Effective Practice with e-Learning. HEFCE: London.

Jung, I., Choi, S., Lim, C., and Leem, J. (2002). Effects of Different Types of Interaction on Learning Achievement, Satisfaction and Participation in Web-Based Instruction, Innovations in Education and Teaching International, 39, 2 pp. 153-162.

Knight, L. and Steinbach, T. (2011). Adapting Peer Review to an Online Course: An Exploratory Case Study, Journal of Information Technology Education, 10, pp 1-20

Moore, M. G. (1993). Three Types of Interaction. In Harry, K., John, M. and Keegan, D. (eds) Distance Education: New Perspectives. Routledge: London.

Moore, M. G. and Kearsley, G. (1996). Distance Education. Wadsworth Publishing Company: Belmont.

Nicol, D. \& Macfarlane-Dick, D. (2006). Formative Assessment and Self-Regulated Learning: A Model and Seven Principles of Good Feedback Practice. Studies in Higher Education, 31, 2 pp.199-218.

Nicol, D. J. \& Milligan, C. (2006). Rethinking Technology-Supported Assessment in Terms of the Seven Principles of Good Feedback Practice. In C. Bryan and K. Clegg (Eds), Innovative Assessment in Higher Education. Taylor and Francis Group Ltd: London.

West, R. E., Waddoups, G., \& Graham, C. R. (2007). Understanding the Experiences of Instructors as they Adopt a Course Management System. Educational Technology Research and Development, 55, 1, 1-26.

\section{Author Biography}

Nola Stair is a principal lecturer in International Collaborations and Learning Technology in the Business School's Department of Systems Management \& Strategy. She has published in the areas of e-Learning/ Instructional Design Technology and presented at various international conferences. 